\title{
How factors affecting farmers job satisfaction in the agricultural sector of Khyber Pakhtunkhwa, Pakistan
}

\author{
Amjad Ali ${ }^{1}$, Maaz Ud Din ${ }^{2}$, Muhammad Nawaz ${ }^{3}$ and Quaid Hussain ${ }^{4 *}$ \\ 1. Department of Management Science, University of Okara-Pakistan \\ 2. Department of Management Sciences, University of Swabi Khyber Pakhtunkhwa-Pakistan \\ 3. School of Economics \& Management, Beijing University of Chemical Technology-China \\ 4. Oil Crops Research Institute of the Chinese Academy of Agricultural Sciences-China \\ *Corresponding author's email: quaid_hussain@yahoo.com
}

Citation

Amjad Ali, Maaz Ud Din, Muhammad Nawaz and Quaid Hussain. How factors affecting farmers job satisfaction in the agricultural sector of Khyber Pakhtunkhwa, Pakistan. Pure and Applied Biology. Vol. 10, Issue 4, pp1047-1062. http://dx.doi.org/10.19045/bspab.2021.100109

\begin{tabular}{llll}
\hline \hline Received: 02/10/2020 & Revised: 18/12/2020 & Accepted: 03/01/2021 & Online First: 08/01/2021 \\
\hline \hline
\end{tabular}

\section{Abstract}

This study aimed to identify factors affecting farmer's satisfaction in the agriculture sector of Khyber Pakhtunkhwa, Pakistan. The factors included in this study were person-job fit, employee empowerment, person-organization fit, self-efficacy, leadership, workload, salary, promotion opportunity, employee training, teamwork, and work environment on job satisfaction of farmers in the agricultural sector of Khyber Pakhtunkhwa, Pakistan. The data was collected through a non-random sample of 502 small farm business participants funded by the Malaysian Knowledge Synthesis Grants Global Research Foundation. The questionnaires were distributed in different regions in the Malakand Division of the Khyber Pakhtunkhwa and analyzed the data through SPSS (Statistical Packages for Social Sciences) and SEM (Structure equation modeling) accordingly. The results show that employee empowerment, person-job fit, self-efficacy, person-organization fit, leadership, salary, promotion opportunity, teamwork, and employee training positively impact farmers' satisfaction levels. However, the workload and work environment adversely impact the farmer's satisfaction levels. The study concluded that by assigning meaningful tasks, assessing existing compensation, professional recognition, and creating a working environment that encourages and inspires farmers. This research helps better understand the various elements of farmers' satisfaction and provides input to improve the Malakand Division agricultural sector's productivity in Khyber Pakhtunkhwa-Pakistan.

Keywords: Confirmatory Factor Analysis, Farmers Job Satisfaction, Structural Equation Modelling

\section{Introduction}

Job satisfaction is widely considered a sector-agnostic for any firm's operations and is a crucial indicator of success and productivity [1]. Greater importance is accorded to job satisfaction issues as workers' satisfaction has a favorable relationship with the attainment of individuals and firms' long-term goals.
Any organization's ability to achieve its strategic goals depends vitally on its capacity to maintain, attract, and retain capable and satisfied workers [2]. Thus, job satisfaction is an exciting area, with many researchers studying the factors contributing to their work satisfaction in the agriculture sector [3]. The worker will be more committed and satisfied in those 
occupations, which tend to be important and vice versa [4]. According to [5], Job satisfaction is a multidimensional and complex construct, meaning different things. In a highly modest business environment, work is the most important characteristic in a person's life because most people's time is spent at work, and worker's job satisfaction is more important than ever [6]. However, lack or absence of job satisfaction may lead to job dissatisfaction, absenteeism, exhaustion, indifference, and rotation, directly or indirectly affecting personal productivity. [7] believe that job satisfaction can significantly promote the productivity, profitability, and efficiency of organizations in various industries, including agriculture, service, and manufacturing industries.

This study focuses on agricultural workers in some private firms in the Khyber Pakhtunkhwa (KPK) province of Pakistan. Its main objective is to identify critical elements such as person-organization fit, person-job fit, employee empowerment, employee self-efficacy, leadership, workload, salary, promotion opportunities, teamwork, employee training, and work environment to work employee job satisfaction. This research endeavor is timely needed because it highlights important aspects of enhancing job satisfaction concerning the agriculture sector in Pakistan, which is the national economy's backbone to infuse greater productivity. The study's findings will serve as a stepping stone to hire, supervise, and develop new strategies and policies for enhancing job satisfaction within the realms of running a farming business [5]. Additionally, this study endeavors to propose strategies to mitigate workers' displeasure, creating a platform for future investigations, and providing benchmarks for upcoming researchers. In the light of the preceding discussion, the purpose of this research is to investigate the associations among employee self-efficacy, person-job fit, employee empowerment, person-organization fit, employee training, leadership, workload, salary, job satisfaction, promotion opportunity, teamwork, and work environment in the agricultural sector of KPK province, Pakistan.

The construct of job satisfaction is gaining heightened attention because of its universality and importance to broad spectra of industries, especially agriculture, widely acclaimed as the Pakistan economy's backbone [8]. Organizational psychologists and industry researchers have published numerous research articles and reports on job behaviors and motivations in the agriculture sector's domains. By the early 20th century, job satisfaction in the literature was already remarkable and significant about job satisfaction in the Western world. [9] noted that from 1935 to 1976 , more than 3,000 research studies were published, making it, on average, one study every five days. According to [10], managers now believe that it is their moral responsibility to germinate high worker satisfaction levels, mainly to enhance their control over efficiency, performance, absenteeism, and job-hopping. This is one of the many reasons why work satisfaction is a common concern for practitioners and researchers in many fields, including but not limited to industrial psychology, business, public administration, and agriculture and higher education sectors. Studying work attitudes and people's feelings about work have become an important research field in organizational behavior and productivity analysis [11]. Based on the previous discussion about the importance of job satisfaction, it is naturally interesting to study and further evaluate farmer satisfaction factors.

Moving ahead in the same vein, we are now discussing empowerment, person-job, and person-organization fit in the context of research. According to [12], the concept of empowerment stems from job enrichment, participative management, and industrial democracy. [13] define 
empowerment as the greater involvement and participation of workers leading to improved decision-making, which is useful for the organization of all sizes. The person-job fit can be defined as the degree to which a person's abilities, knowledge, needs, skills, values, and preferences align with his job or job requirements [14]. Employees with a high degree of PersonJob (P-J) fit indicate that their performance and job satisfaction are high. Most researchers define it as a matching process between an organization and an individual. According to [15], P-O matching is divided into two main categories: additional matching and complementary matching. The former is achieved when a person has similar characteristics to others in the organization. On the contrary, when a person's characteristics add something new to fill the gaps in organizational knowledge and skills, thereby creating value for himself and others, the latter can be achieved.

In the same continuation, the concept of self-efficacy, leadership, workload, and promotion or advancement in farmers' lives is discussed in ensuing lines. Selfefficacy refers to 'people's judgments of their abilities to organize and perform the course of action needed to achieve a designated type of performance [16]. Many scholars believe that self-efficacy is closely related to job satisfaction in various departments [17]. At the same time, leadership is a term that can be found in all workspaces and defined in many ways. [18] believe that leadership manages teamwork under appropriate control and influence. Similarly, [19] define leadership to guide organized people to achieve their goals. [20] describe workload as the work environment requirements for workers in the same vein. The qualitative workload is related to difficulty in physical or mental tasks, while the quantitative workload is related to worker output. [21] reported that job satisfaction correlates positively with that of employee's salaries. Managers within the organization or new entrepreneurs such as farmers strive to improve their quality of life, income prospects, and labor mobility to increase workplace productivity [22].

[23] posited that training could be divided into on-the-job and off-the-job training, with the former undertaken internally and later outside organizational boundaries. Teamwork enables workers to co-operate, enhance personal skills, and provide an adequate response without any conflict among fellows [24]. Teamwork as a strategy can improve employees and the organization's performance, but it must be developed over time to improve performance in an increasingly competitive environment [25]. It naturally makes sense that individuals who feel relaxed in their workplace are more productive and enjoy the workflow more than those who feel otherwise, which makes aspects of the employee's work environment more critical in the study. Some problems may hinder the relaxation of the environment, such as noise, ventilation, hygiene of the workspace, and pressure. Work stress can be caused by various reasons, such as the nature of work, work location, monotony, repetition, payment system, shift work, and colleague's attitude. [26] proclaims that many workers respond differently to different situations. However, it is hard to eliminate stress wholly faced by farmers beyond their control, but experts assert that some form of stress is useful as it brings out the best in certain situations.

\section{The objective of the study}

To examine how factors affecting farmers Job Satisfaction in the Agricultural sector of Khyber Pakhtunkhwa, Pakistan.

\section{Materials and Methods}

The study uses a quantitative research design to check the hypotheses of association among independent and dependent variables, such as employee empowerment, P-O fit, P-J fit, employee training, leadership, workload, salary, promotion opportunity, teamwork, employee self-efficacy, and work 
environment - on employee job satisfaction in the agricultural sector of the District Malakand of KPK, Pakistan. We chose a causal study for examining the natural environment to reduce the level of interference with the researcher taking a neutral stance [27]. We used a crosssectional survey design to analyze data for results. For the data collection, we used the questionnaire survey technique for the measurement, and the sample design was non-random purposive of sample 502 participants in line with [28] to ensure a representative sample is used. The variable employee empowerment, P-O fit, P-J fit, employee self-efficacy was measured through the construct as developed by [28-
30]. The variable Leadership style, workload, salary, and promotion opportunity were measured through the construct developed by [31-34]. Whereas the variable employee training, teamwork, and work environment were measured through the construct as developed by [35] and [36]; while, variable job satisfaction was measured through the construct as developed by [37]. In the current research, Cronbach $\alpha$ was used to calculate the reliability by using SPSS. In addition, CFA (confirmatory factor analysis) was used to measure the validity, structural equation modeling (SEM) was also used to test model fitness, and using AMOS 21 software. (Fig. 1).

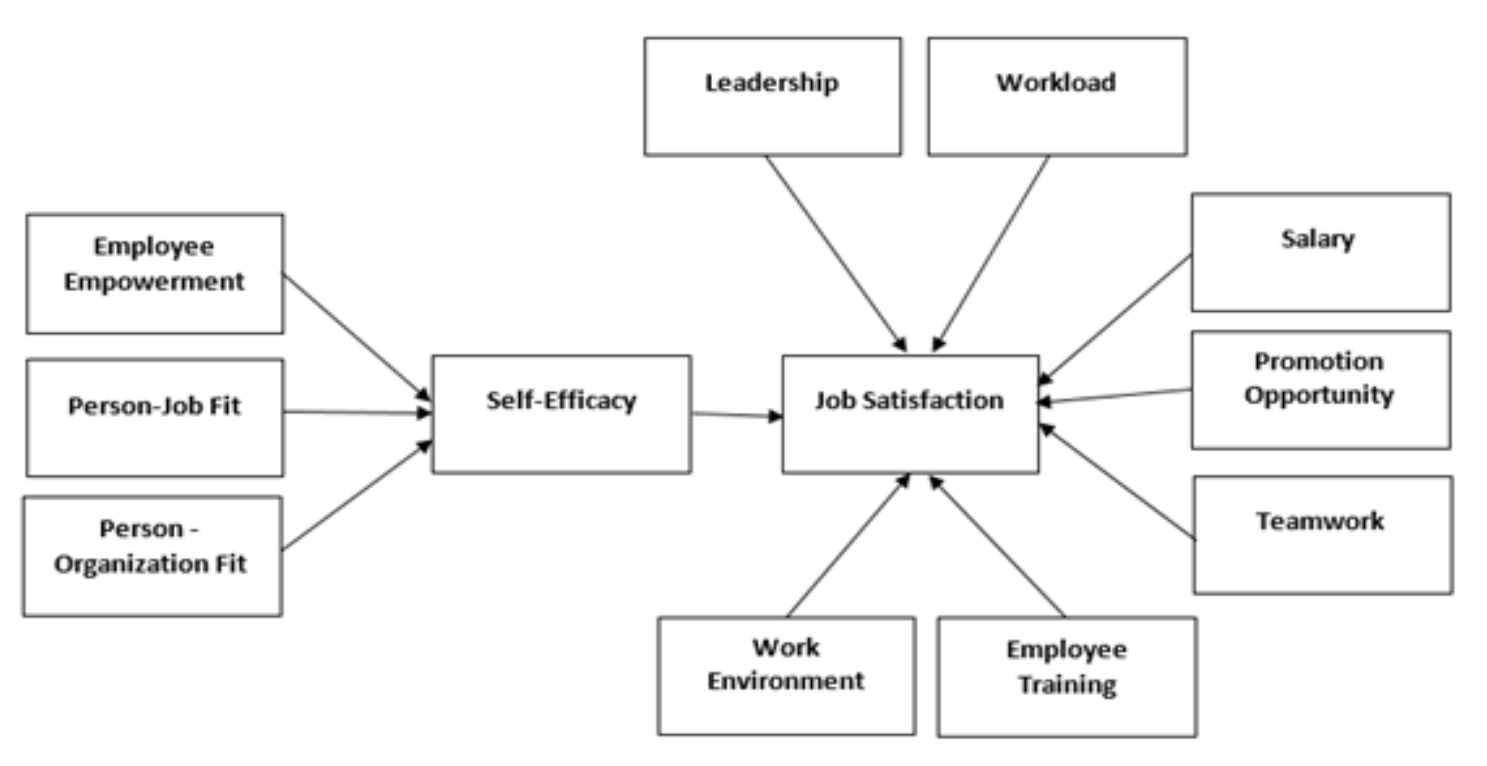

Figure 1. The conceptual model

\section{Results}

The results have been given clearly and concisely furnished with the elaboration of figures and tables. As per the research objectives, we summarized the effects of eleven elements - employee empowerment, P-J fit, self-efficacy, P-O fit, leadership, workload, salary, promotion opportunity, teamwork, training, and work environment - on job satisfaction of employee in the agricultural sector, of the KPK-Pakistan in the ensuing discussion.

Respondent's demographic information Descriptive analysis was employed to identify the demographic information of the interviewees. The results of (Table 1) shows that out of 502 respondents, $16.9 \%$ were female respondents, while $83.1 \%$ were male respondents. In terms of age group, most of the respondents, 54\%, were in the range of 31 to 40 years, followed by $41-50$ years $(19.5 \%)$. The age category of 21-30 years constitutes $14.1 \%$ of the sample size. The smallest group was those above 51 years old (12.4\%). The results of (Table 1) illustrates that of the 502 respondents who participated, $73.9 \%$ of the respondents were married, while the 
remaining $26.1 \%$ were unmarried. In terms of education, $2.7 \%$ of the respondents' had an MS degree, $32.5 \%$ a master's degree, $16.5 \%$ a high school certificate, $30.9 \%$ a BS/bachelor's degree, While $17.3 \%$ had a diploma or lower level qualification. Regarding the respondent's job contract information, only $4.6 \%$ of the respondents worked in the existing organization for more than nine years, $12.0 \%$ worked for six to nine years, $39.6 \%$ work for three to six years, $37.8 \%$ worked for one to three years respectively. While the remaining $6.0 \%$ of the respondents had less than one year of work experience in the current organizational setup. $18.1 \%$ of the respondents earn between PKR 20001 to 30000 per month, while $28.7 \%$ earn between PKR 30001 to PKR 40000 per month. Similarly, $37.1 \%$ of the respondents earn between PKR 40001 to 50000 per month, while $11.8 \%$ earn between PKR 50001 and PKR 60000 per month. Only $1.8 \%$ of the respondents earn more than PKR 60000 per month. Similarly, $2.6 \%$ of the respondents had income in the range of PKR 20000 or under. See (Table 1) for more details on demographic variables.

Table 1. Demographic details of the sample

\begin{tabular}{|c|c|c|c|}
\hline Variable & Value & Frequency & Valid $(\%)$ \\
\hline \multirow[t]{2}{*}{ Gender } & Male & 417 & 83.1 \\
\hline & Female & 85 & 16.9 \\
\hline \multirow[t]{4}{*}{ Age } & 21-30 years & 71 & 14.1 \\
\hline & $31-40$ years & 271 & 54 \\
\hline & 41-50 years & 98 & 19.5 \\
\hline & Above 51 years & 62 & 12.4 \\
\hline \multirow[t]{2}{*}{ Marital Status } & Unmarried & 131 & 26.1 \\
\hline & Married & 371 & 73.9 \\
\hline \multirow[t]{5}{*}{ Qualification } & M.Phil. & 14 & 2.7 \\
\hline & Master & 163 & 32.5 \\
\hline & Undergraduate & 155 & 30.9 \\
\hline & Intermediate & 83 & 16.5 \\
\hline & Diploma & 87 & 17.3 \\
\hline \multirow[t]{5}{*}{ Experience } & Less than one year & 30 & 6.0 \\
\hline & One-three years & 190 & 37.8 \\
\hline & Three-six years & 199 & 39.6 \\
\hline & Six-nine years & 60 & 12.0 \\
\hline & Above nine years & 23 & 4.6 \\
\hline \multirow[t]{6}{*}{ Monthly income (Rupees) } & PKR 20000 or under & 13 & 2.6 \\
\hline & PKR 20001 to 30000 & 91 & 18.1 \\
\hline & PKR 30001 to 40000 & 144 & 28.7 \\
\hline & PKR 40001 to 50000 & 186 & 37.1 \\
\hline & PKR 50001 to 60000 & 59 & 11.8 \\
\hline & Above than PKR 60000 & 9 & 1.8 \\
\hline Total participants & & 502 & 100 \\
\hline
\end{tabular}

Validity and reliability analysis

The results of (Table 2) shows that the current research adopted the construct and items from other multiple research studies which measured employee empowerment, P-J fit, self-efficacy, P-O fit, leadership, 
workload, salary, promotion opportunity, teamwork, employee training, work environment, and job satisfaction. The survey questionnaire was modified for the goodness of measure for perceptual constructs the validity of variables fit. 11 factors employee empowerment, P-J fit, self-efficacy, P-O fit, leadership, workload, salary, promotion opportunity, teamwork, employee training, work environment, and job satisfaction were extracted with 49 items and AVE (average variance extracts) resulted in $0.577,0.572,0.539,0.570$, $0.594,0.557,0.587,0.567,0.548,0.581$, 0.541 , and 0.597 , respectively. [38] recommends that Cronbach's alpha is used to test the reliability of factor analysis with an acceptable value for the internal consistency of the construct. The Cronbach's alpha value is generally considered to be 0.70 . Likewise, the value of Cronbach's alpha of employee empowerment, P-J fit, self-efficacy, P-O fit, and leadership are $0.868,0.835,0.821$, 0.839 , and 0.852 , while for workload, salary, promotion opportunity, teamwork, employee training, work environment, and job satisfaction, the Cronbach's alpha value are $0.790,0.806,0.835,0.853,0.869$, 0.854 , and 0.850 respectively, which are acceptable.

Table 2. Confirmatory factor analysis

\begin{tabular}{|c|c|c|c|c|}
\hline Code & Items & $\begin{array}{c}\text { Factor } \\
\text { Loadings }\end{array}$ & EVE & Reliability \\
\hline & Employee Empowerment & & 0.577 & 0.868 \\
\hline EEI & I got more facilities to carry out my job & 0.820 & & \\
\hline EE2 & $\begin{array}{l}\text { I provide plenty of important information to } \\
\text { get the job done }\end{array}$ & 0.859 & & \\
\hline EE3 & $\begin{array}{l}\text { I can use my authority and have the right to } \\
\text { decide and performed my job well }\end{array}$ & 0.805 & & \\
\hline EE4 & $\begin{array}{l}\text { My boss motivates me always which in turn } \\
\text { give me the confidence to make the right } \\
\text { decision in my job }\end{array}$ & 0.732 & & \\
\hline \multirow[t]{2}{*}{ EE5 } & I am free in my job whatever how I do my job & 0.801 & & \\
\hline & Person-Job Fit & & 0.572 & 0.835 \\
\hline PJF1 & $\begin{array}{c}\text { There is a similarity between what I am } \\
\text { looking for in a job and what my job offers } \\
\text { me }\end{array}$ & 0.746 & & \\
\hline PJF2 & $\begin{array}{l}\text { The characteristics that I look for in a job are } \\
\text { fulfilled very well in my current job. }\end{array}$ & 0.799 & & \\
\hline PJF3 & $\begin{array}{l}\text { The similarities are excellent between the } \\
\text { demands of my job and my expertise. }\end{array}$ & 0.849 & & \\
\hline \multirow[t]{2}{*}{ PJF4 } & $\begin{array}{l}\text { The job that I currently hold gives me just } \\
\text { about everything I want from a job. }\end{array}$ & 0.789 & & \\
\hline & Person-Organization Fit & & 0.539 & 0.821 \\
\hline POF1 & $\begin{array}{l}\text { The placement of an organization is a good } \\
\text { match for me. }\end{array}$ & 0.807 & & \\
\hline POF2 & $\begin{array}{l}\text { My personality matches the reputation of the } \\
\text { placement of the organization. }\end{array}$ & 0.756 & & \\
\hline POF3 & $\begin{array}{l}\text { The placement of the organization fulfills my } \\
\text { needs }\end{array}$ & 0.746 & & \\
\hline
\end{tabular}




\begin{tabular}{|c|c|c|c|c|}
\hline POF4 & $\begin{array}{l}\text { The values of the placement of the } \\
\text { organization, similar to my values. }\end{array}$ & 0.792 & & \\
\hline & Self-Efficacy & & 0.570 & 0.839 \\
\hline SE1 & $\begin{array}{l}\text { Whenever I face any problem, I can manage } \\
\text { to solve that problem by using my skills. }\end{array}$ & 0.780 & & \\
\hline SE2 & $\begin{array}{l}\text { If someone does not agree with me, I can find } \\
\text { the means and different ways to get what I } \\
\text { want. }\end{array}$ & 0.784 & & \\
\hline SE3 & $\begin{array}{l}\text { I am inquisitive about my job; that's why easy } \\
\text { for me to accomplish my goals. }\end{array}$ & 0.747 & & \\
\hline SE4 & $\begin{array}{l}\text { I am confident when I face unexpected events } \\
\text { and deal with them. }\end{array}$ & 0.828 & & \\
\hline & Leadership & & 0.594 & 0.852 \\
\hline LS1 & $\begin{array}{l}\text { I am aware of the abilities of my immediate } \\
\text { boss's towards the employees. }\end{array}$ & 0.761 & & \\
\hline $\mathrm{LS} 2$ & $\begin{array}{l}\text { I am satisfied with the style of my boss's } \\
\text { directions. }\end{array}$ & 0.818 & & \\
\hline LS3 & $\begin{array}{l}\text { I am satisfied with the support of my } \\
\text { manager. }\end{array}$ & 0.787 & & \\
\hline LS4 & $\begin{array}{l}\text { I am satisfied with the managerial skills of my } \\
\text { boss. }\end{array}$ & 0.817 & & \\
\hline & Workload & & 0.557 & 0.790 \\
\hline WL1 & $\begin{array}{c}\text { My colleagues are not doing their jobs } \\
\text { properly that's why my workload is often } \\
\text { increased }\end{array}$ & 0.796 & & \\
\hline WL2 & Sometimes I face pressure at work & 0.803 & & \\
\hline WL3 & 1 am expected that I am working to much & 0.810 & & \\
\hline & Salary Package & & 0.587 & 0.806 \\
\hline SP1 & $\begin{array}{l}\text { The Company where I am working the } \\
\text { remuneration package is competitive. }\end{array}$ & 0.797 & & \\
\hline SP2 & $\begin{array}{c}\text { I am much satisfied with the entirety of my } \\
\text { salary package. }\end{array}$ & 0.827 & & \\
\hline SP3 & $\begin{array}{c}\text { If I found better opportunities than the current } \\
\text { job, I will leave this organization } \\
\text { immediately. }\end{array}$ & 0.821 & & \\
\hline & Promotion Opportunity & & 0.567 & 0.835 \\
\hline PO1 & $\begin{array}{l}\text { For expanding my knowledge, I am allowed } \\
\text { to attend different workshops, seminars, and } \\
\text { conferences }\end{array}$ & 0.767 & & \\
\hline $\mathrm{PO} 2$ & $\begin{array}{l}\text { Different in-service education programs } \\
\text { leading to promotions are available. }\end{array}$ & 0.790 & & \\
\hline PO3 & $\begin{array}{l}\text { I work hard to express my professional } \\
\text { developmental needs. }\end{array}$ & 0.814 & & \\
\hline
\end{tabular}


Ali et al.

\begin{tabular}{|c|c|c|c|c|}
\hline PO4 & $\begin{array}{l}\text { The Promotion criteria of my organization are } \\
\text { well defined. }\end{array}$ & 0.822 & & \\
\hline & Teamwork & & 0.548 & 0.853 \\
\hline TW1 & $\begin{array}{l}\text { The team members have a strong association } \\
\text { with each other }\end{array}$ & 0.749 & & \\
\hline TW2 & The team members give respect to every one & 0.812 & & \\
\hline TW3 & $\begin{array}{l}\text { My department team member always support } \\
\text { me during my work }\end{array}$ & 0.796 & & \\
\hline TW4 & $\begin{array}{l}\text { work hard is the motive of my team member } \\
\text { to get things done }\end{array}$ & 0.799 & & \\
\hline TW5 & $\begin{array}{c}\text { For the accomplishment of their job my team } \\
\text { member encourages one another }\end{array}$ & 0.673 & & \\
\hline & Employee Training & & 0.581 & 0.869 \\
\hline ET1 & $\begin{array}{c}\text { For staff development, my department } \\
\text { management organizes different seminars } \\
\text { and conferences to respond to the changing } \\
\text { needs of work }\end{array}$ & 0.669 & & \\
\hline ET2 & $\begin{array}{l}\text { The reward system is fundamental in my } \\
\text { department to encourage their employees }\end{array}$ & 0.793 & & \\
\hline ET3 & $\begin{array}{l}\text { The training opportunities which I got well } \\
\text { suited my job }\end{array}$ & 0.787 & & \\
\hline ET4 & $\begin{array}{l}\text { My expectations are fulfilled my training } \\
\text { program }\end{array}$ & 0.783 & & \\
\hline ET5 & $\begin{array}{l}\text { By conducting a different training program } \\
\text { which I got feel satisfied me }\end{array}$ & 0.861 & & \\
\hline & Work Environment & & 0.541 & 0.854 \\
\hline WE1 & $\begin{array}{l}\text { I feel that my workplace is a safe } \\
\text { environment. }\end{array}$ & 0.756 & & \\
\hline WE2 & $\begin{array}{l}\text { I am satisfied with the supporting equipment I } \\
\text { use to get help in my job. }\end{array}$ & 0.819 & & \\
\hline WE3 & $\begin{array}{l}\text { My occupational health care is good, and I am } \\
\text { happy. }\end{array}$ & 0.805 & & \\
\hline WE4 & $\begin{array}{l}\text { I am pleased with the cleanliness and lighting } \\
\text { of the working place. }\end{array}$ & 0.688 & & \\
\hline & Job Satisfaction & & 0.597 & 0.850 \\
\hline JS1 & I am satisfied with my current working status. & 0.794 & & \\
\hline JS2 & My earning condition feel satisfied me & 0.704 & & \\
\hline JS3 & $\begin{array}{l}\text { I am so happy to select this organization for } \\
\text { my job }\end{array}$ & 0.725 & & \\
\hline JS4 & $\begin{array}{l}\text { I am delighted and curious about my current } \\
\text { job }\end{array}$ & 0.718 & & \\
\hline
\end{tabular}




\section{Structural equation model and model fit index}

Nowadays, mostly SEM (Structural equation modeling) is used by many investigators to evaluate their theories as it offers flexibility and does not rely on a single technique. [39] described that if the $\chi^{2} / \mathrm{df}$ value is between $0-3$, it is considered acceptable. For this current study, the $\chi^{2} / \mathrm{df}$ value is 1.661 , which means the accepted level. The ranges of comparative fit index (CFI), adjusted goodness-of-fit index (AGFI), TuckerLewis index (TLI), and goodness-of-fit index (GFI) are between 0-1, and the values close to 1 indicate that the model is a well suited or perfect fit. For this study, the values of $\mathrm{AGFI}=0.836, \mathrm{CFI}=0.931$, TLI $=0.927$, and GFI $=0.851$ which are considered acceptable for this study. The benchmark value of root means a square error of approximation (RMSEA) is below 0.08 , which shows a good model fit. This study benchmark value is 0.036 , which is considered acceptable (Fig. 2 \& Table 3 ).

Regression weight for hypothesis testing As per the theoretical model, the structural equation modeling presented above in (Fig. 2) indicates the associations between the dependent and independent variables of interest phenomena. Estimation of regression coefficients determined in (Table 4) showed that employee empowerment, person-organization, and fit person job fit positively affect employee self-efficacy with values of $0.250,0.621$, and 0.342 . Self-efficacy positively relates to job satisfaction with a value of 0.240 , while workload and work environment slightly negatively affected employee job satisfaction (-0.047, -0.035). Furthermore, leadership, salary, promotion opportunity, teamwork, and employee training have positively affected the employee job satisfaction with value ranges $0.202,0.282$, $0.280,0.213$, and 0.276 accordingly (Table $4)$.

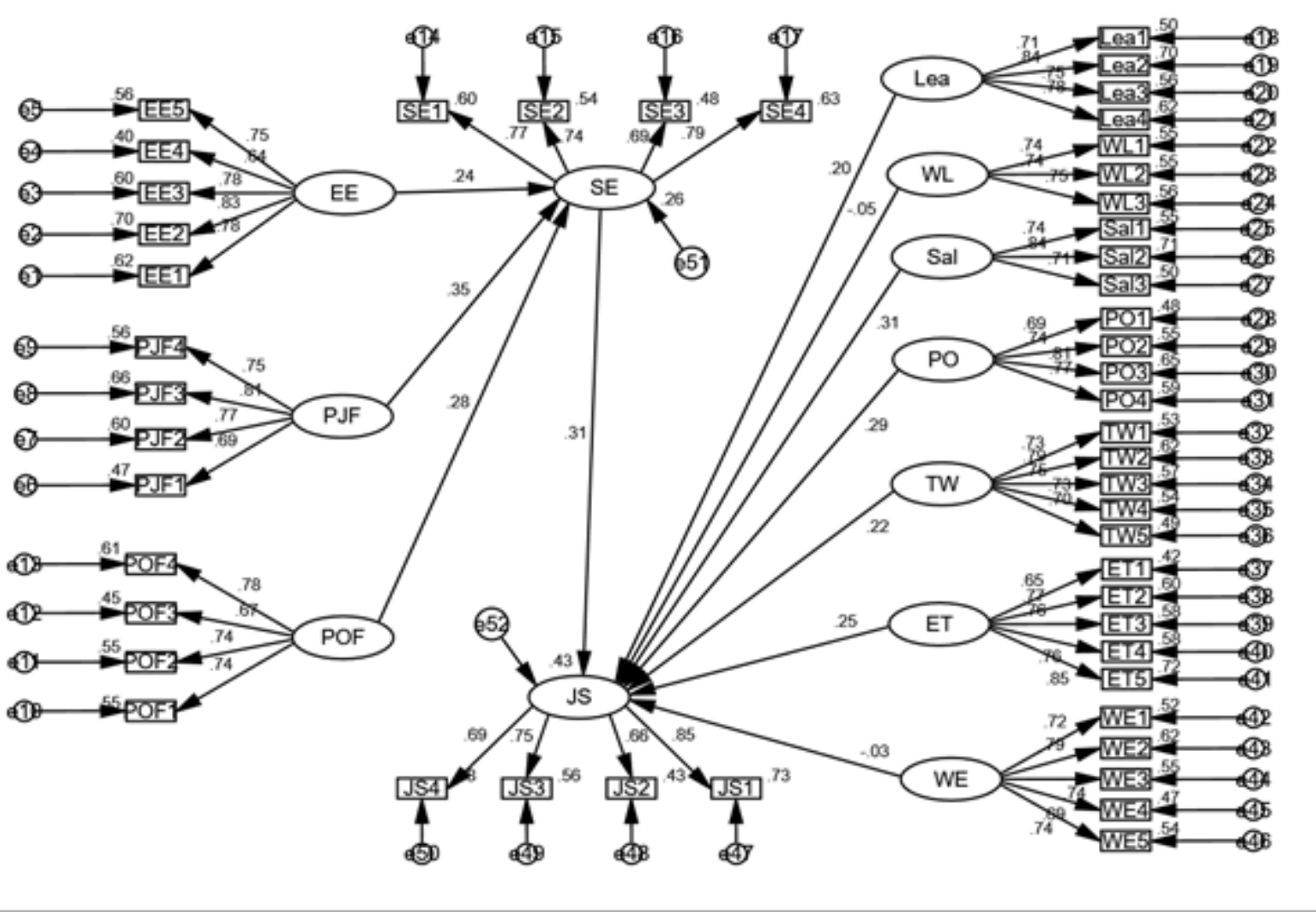

Figure 2. Structural equation model fitness for study 
Table 3. Model goodness of fit measures

\begin{tabular}{|c|c|c|c|c|}
\hline Fit indices & $\begin{array}{c}\text { Accepta } \\
\text { ble Level }\end{array}$ & $\begin{array}{c}\text { Measured } \\
\text { value }\end{array}$ & $\begin{array}{c}\text { Benchmark } \\
\text { paper }\end{array}$ & Decision \\
\hline CFI & $>0.90$ & 0.931 & {$[40]$} & Acceptable \\
\hline TLI & $>0.90$ & 0.927 & {$[41]$} & Acceptable \\
\hline GFI & $>0.80$ & 0.851 & {$[42]$} & Acceptable \\
\hline AGFI & $>0.80$ & 0.836 & {$[42]$} & Acceptable \\
\hline NFI & $>0.80$ & 0.843 & {$[41]$} & Acceptable \\
\hline P-CLOSE & $>0.50$ & 1.000 & {$[43]$} & Acceptable \\
\hline RMSEA & $<0.08$ & 0.036 & {$[44]$} & Acceptable \\
\hline $\mathrm{X}^{2}$ & & 1933.602 & & \\
\hline DF & & 1164 & & \\
\hline Chi-square $\left(\mathrm{X}^{2} / \mathrm{DF}\right)$ & $>1<3$ & 1.661 & {$[45]$} & Acceptable \\
\hline
\end{tabular}

Table 4. Hypotheses testing

\begin{tabular}{|c|c|c|c|c|c|c|c|}
\hline $\begin{array}{c}\text { Hypothesi } \\
\text { S }\end{array}$ & $\begin{array}{c}\text { Independent } \\
\text { Variable }\end{array}$ & $\begin{array}{c}\text { Dependent } \\
\text { Variable }\end{array}$ & Estimate & S.E. & C.R. & $\begin{array}{c}\text { P- } \\
\text { Value }\end{array}$ & Decision \\
\hline HI & Empowerment & Self-efficacy & 0.250 & 0.051 & 4.906 & $* * *$ & Supported \\
\hline H2 & Person-job fit & Self-efficacy & 0.621 & 0.093 & 6.673 & $* * *$ & Supported \\
\hline H3 & $\begin{array}{c}\text { Person- } \\
\text { organization } \\
\text { fit }\end{array}$ & Self-efficacy & 0.342 & 0.062 & 5.484 & $* * *$ & Supported \\
\hline H4 & Self-efficacy & Job satisfaction & 0.240 & 0.036 & 6.695 & $* * *$ & Supported \\
\hline H5 & Leadership & Job satisfaction & 0.202 & 0.048 & 4.196 & $* * *$ & Supported \\
\hline H6 & Workload & Job satisfaction & -0.047 & 0.048 & -0.98 & 0.327 & Rejected \\
\hline H7 & Salary & Job satisfaction & 0.282 & 0.045 & 6.337 & $* * *$ & Supported \\
\hline H8 & $\begin{array}{c}\text { Promotion } \\
\text { opportunity }\end{array}$ & Job satisfaction & 0.280 & 0.047 & 6.015 & $* * *$ & Supported \\
\hline H9 & Teamwork & Job satisfaction & 0.213 & 0.047 & 4.571 & $* * *$ & Supported \\
\hline H10 & Training & Job satisfaction & 0.276 & 0.055 & 5.044 & $* * *$ & Supported \\
\hline H11 & $\begin{array}{c}\text { Work } \\
\text { environment }\end{array}$ & Job satisfaction & -0.035 & 0.049 & -0.72 & 0.470 & Rejected \\
\hline
\end{tabular}

\section{Discussion}

This study has been used to determine the important factors (empowerment, P-J fit, P-O fit, leadership, workload, salary, promotion opportunity, teamwork, employee training, work environment) that affect the job satisfaction of employees working in the agricultural sector of the KPK, Pakistan, mediated by self-efficacy, resulting in relationships between variables. This study found that employee empowerment positively affects employee self-efficacy and goes in agreement with prior research [46]. Many studies show that job empowerment strategies can increase employees' self-efficacy. The study found that work-related fitness has a significant positive effect on employee performance. This study's results are consistent with previous studies undertaken in developing countries [46, 47]. According to social knowledge theory, workers with greater autonomy will pursue higher goals, perform better in the workplace, and earn more appreciation, salary, and career advancement 
opportunities [48]. Person-organization fit can significantly impact employee selfefficacy and was supported by previous research [35]. According to the personorganization fit theory, when employees' values are congruent with their organizational values, they will have positive attitudes and behaviors [49]. This study suggests that workers can be advised to identify organizations with similar values in their job search in career counseling or mentoring. Workers who are farmers, in this case, with low-value fit may be challenging to identify with their organization, which may have a negative influence on their self-efficacy, commitment, and job satisfaction [50]. This study investigates that employee selfefficacy significantly influences employee job satisfaction and has been supported by previous research [51]. With the improvement of self-efficacy, the workforce can more easily adapt to changing environments. Therefore, individuals with higher self-efficacy tend to be more positive and active in their employment and working environment, contributing to their work satisfaction. In addition, individuals with higher selfefficacy tend to remain highly persistent in the face of failure and effectively overcome difficulties. Once strong selfefficacy is achieved, individuals are likely to be happy with their employment.

Moreover, this study found that leadership has a significant favorable influence on employee job satisfaction and has been supported by previous research [52, 53]. These research results are consistent with the transformational leadership theory, emphasizing leaders' role in providing a supportive work environment for employees, thereby increasing satisfaction and productivity [54]. Moreover, leadership styles and organizational culture are critical organizational antecedents of job satisfaction. Leadership and job satisfaction are considered significant components that influence the organization's overall productivity [55].
This study found that the workload had a negative and insignificant impact on employee job satisfaction, and the results didn't provide support for this hypothesis. This finding was supported by many researchers earlier [56], who found that the workload is insignificantly linked with employees' job satisfaction. The rise in the workload of personnel is inversely related to the job satisfaction of workers. The decline in job satisfaction is generally considered related to anxiety, anger, tension, depression, and fatigue [57]. Excessive workload leads to increased mental and physical stress and dissatisfaction. Hence, we can argue that the more organizational tasks and the number of hours of work per week were associated with emotional exhaustion, which manifests burnout and employee job dissatisfaction. However, salary had a positive and significant influence on employee job satisfaction, and the results support this hypothesis. This financing has been supported by several researchers [58, 59], who found that pay is the essential variable for job satisfaction. If a person is paid more, the performance of the individual is likely to rise. [60] stated that Herzberg's theory of motivation-hygiene tells us that pay is one of the hygienic factors that reduce job dissatisfaction. The study also found that promotion opportunities significantly affect employee satisfaction and that the results support this assumption. The results of this study are consistent with previous studies undertaken $[61,62]$.

Teamwork can significantly impact employee job satisfaction, and the results also support our hypothesis for this study. Researchers such as [63] and [64] support this finding, and they believe that teamwork plays a crucial role in improving employee job satisfaction. In these environments, teamwork efforts will positively affect employee job satisfaction, as the study results show following [65]. This study found that employee training has a positive effect on job satisfaction for 
work. It has a positive effect and has been supported by previous research done by [66]. Training plays a crucial role in building new and existing employees, as it helps them perform their job effectively. Training also prepares staff for upcoming positions in an organization with full capacity and helps overcome gaps in workrelated areas. Many researchers have found that the right work environment was related to higher job satisfaction, lower job burnout, and less willingness to leave [53].

\section{Conclusions and Recommendations}

The results argue empirically that employee empowerment, person-job fit, self-efficacy, person-organization fit, leadership, salary, promotion opportunity, teamwork, and employee training have a positive impact on farmers satisfaction level in the context of the study. It has been concluded that the workload and work environment adversely impact the farmer's satisfaction levels. The study concluded that assignment of meaningful tasks, assessing existing compensation, professional recognition, and creating a working environment that encourages and inspires farmers improves satisfaction levels. The results indicate that Person-job fit plays a key role in farmer's productivity decreases turnover intention, and improves farmers' work satisfaction, improving their self-efficacy level. Intervention, both internal and external, is required to improve worker's person-organization fit perceptions. The study indicates that selfefficacy can also influence job-related pressure employees experience when dealing with various demands. Our findings suggest that supervisory employees should consider increasing worker's confidence when deciding how to improve job satisfaction.

Moreover, a leadership style that involves workers in the decision-making process will provide farmers with even more satisfying opportunities. Likewise, a positive work environment can motivate good organizational leadership and contribute to organizational success in the agriculture sector of Khyber Pakhtunkhwa. The study indicates that workers in the farm business who perceive the workload as unfair are more likely than others to execute poorly and may require closer scrutiny and more support and supervision. Salary or compensation is an invaluable tool for retention and a motivational factor for employee's commitment to the organization, improving attraction and retention. Regarding advancement, workers will be more satisfied if their jobs provide personal and career advancement opportunities, which determines the degree of employee satisfaction. Likewise, teamwork and training positively impact farmer's job satisfaction, making it imperative in contemporary practices. To improve employee's efficiency, productivity, and commitment to work, organizations must meet their staff's needs by providing the right working environment. As the agriculture sector relies heavily on human resources, managers must increase job satisfaction within farming businesses to motivate farmworkers through meaningful tasks, reassessing compensation, professional recognition, and creating a working environment that encourages and inspires workers. The researchers suggest that future research used other variables such as perceived organizational support and self-efficacy also different sectors like telecom, health, and education. The study examines the effects of an extended set of eleven elements on farmers' job satisfaction, unlike prior researchers who had paid scarce attention as evident from the scant empirical treatment of research area having more than six variables in the agriculture sector Khyber Pakhtunkhwa, Pakistan. Moreover, Structural equation modeling has been used, which amalgamates a family of related methods rather than a single technique, which further adds credence to the study.

\section{Author's Contributions}

Conceived and designed the experiments: A Ali, Performed the experiments: A Ali, 
M U Din, \& M Nawaz, Analyzed the data: A Ali \& Q Hussain, Contributed reagents/materials/analysis tools: A Ali, M U Din, M Nawaz, \& Q Hussain, Wrote the paper: A Ali \& Q Hussain.

\section{References}

1. Lambert EG, Keena LD, Leone M, May D, \& Haynes SH (2020). The effects of distributive and procedural justice on job satisfaction and organizational commitment of correctional staff. The Soci Sci J 57(4): 1-12.

2. Qureshi H, Frank J, Lambert EG, Klahm C, \& Smith B (2017). Organisational justice's relationship with job satisfaction and organizational commitment among Indian police. The Police J 90(1): 3-23.

3. Abbas SG, Yousafzai MT, \& Qureshi MI (2015). Coping the Challenge of Change in Academe--Are we really Learning Organizations? $J$ of $M g t$ Sci 9(1).

4. Zehir C, Erdogan E, \& Basar D (2011). The relationship among charismatic leadership, ethical climate, job satisfaction and organizational commitment in companies. $J$ of Global Str Mgt 10: 49-59.

5. Hanaysha J, \& Tahir PR (2016). Examining the effects of employee empowerment, teamwork, and employee training on job satisfaction. Procedia-Soc and Beh Sci 219: 272-282.

6. Hollingworth D, \& Valentine S (2014). Corporate social responsibility, continuous process improvement orientation, organizational commitment and turnover intentions. Int J of Qual \& Reli Mgt 31(6).

7. Ullah R, \& Ahmad SZ (2018). The Effect of Organizational Politics on Job Stress; Mediating Role of Job Satisfaction. Electronic J of Bus Eth and Org Stu 23(2).

8. Umar H, Tariq S, \& Bacha MS (2019). An empirical assessment of the dynamics of agricultural growth in Pakistan. Sarhad J of Agric 35(3): 782-787.

9. Kooij DT, Jansen PG, Dikkers JS, \& De Lange AH (2010). The influence of age on the associations between HR practices and affective commitment and job satisfaction: A meta-analysis. $J$ of Org Beh 31(8): 1111-1136.

10. Tongchaiprasit $P, \quad \&$ Ariyabuddhiphongs V (2016). Creativity and turnover intention among hotel chefs: The mediating effects of job satisfaction and job stress. Int J of Hospitality Mgt 55: 3340.

11. Abbas SG, Yousafzai MT, \& Khattak A (2015). Internationalization of Universities: Challenges, Threats and Opportunities for Third World Countries. Dialogue (Pak) 10(4).

12. Robbins SP, \& Judge $\mathrm{T}$ (2016). Behavior organizational. Translatey by Parseian A, Arabi M. IST edition, Tehran, Institute of Operational.

13. Dahinten VS, Lee SE, \& MacPhee M (2016). Disentangling the relationships between staff nurses' workplace empowerment and job satisfaction. J of Nursing Mgt 24(8): 1060-1070.

14. Rounds JB, Dawis R, \& Lofquist LH (1987). Measurement of personenvironment fit and prediction of satisfaction in the theory of work adjustment. J of Vocational Beh 31(3): 297-318.

15. Muchinsky PM, \& Monahan CJ (1987). What is person-environment congruence? Supplementary versus complementary models of fit. $J$ of Vocational Beh 31(3): 268-277.

16. Thiel BL, \& Marx AA (2019). The Influence of Agriscience Research SAEs on Perceived Self-Efficacy of 21st Century Skill Attainment. J of Agric Ed 60(1).

17. Havaei F, MacPhee M, \& Susan Dahinten V (2016). RN s and LPN s: 
emotional exhaustion and intention to leave. J of Nursing Mgt 24(3): 393399.

18. Odoardi C, Montani F, Boudrias JS, \& Battistelli A (2015). Linking managerial practices and leadership style to innovative work behavior. Leadership \& Org Deve J $36(5)$.

19. Erkutlu H, \& Chafra J (2018). Despotic leadership and organizational deviance: The mediating role of organizational identification and the moderating role of value congruence. $J$ of Stra and Mgt 11(2): 150-165.

20. Eissa G, \& Lester SW (2017). Supervisor role overload and frustration as antecedents of abusive supervision: The moderating role of supervisor personality. $J$ of $\mathrm{Org}$ Beh 38(3): 307-326.

21. Lu H, Barriball KL, Zhang $X, \&$ While AE (2012). Job satisfaction among hospital nurses revisited: a systematic review. Int $J$ of Nursing Stu 49(8): 1017-1038.

22. Al-dalahmeh $\mathrm{M}$, Khalaf $\mathrm{R}$, \& Obeidat B (2018). The effect of employee engagement on organizational performance via the mediating role of job satisfaction: The case of IT employees in Jordanian banking sector. Mod Applied Sci 12(6): 17-43.

23. Zhou Y, \& Yang X (2013). The risk of trained employee loss and the avoiding strategies. In Int Aca Workshop on Soc Sci (IAW-SC-13). Atlantis Press.

24. Dhar, R. L. (2015). Service quality and the training of employees: The mediating role of organizational commitment. Tourism Mgt 46: 419430.

25. Shen J, \& Tang C (2018). How does training improve customer service quality? The roles of transfer of training and job satisfaction. European Mgt J36(6): 708-716.
26. Lee SS, Stearns TM, Mansor NNA, Tayles M, Pike R, Chinen K, \& YongKean L (2012). Critical Success Factors in the Performance of FemaleOwned 3 Businesses: A Study of Female Entrepreneurs in Korea. Int $J$ of Mgt 29(1).

27. Iqbal T, Yousafzai MT, Ali S, Sattar K, Saleem MQ, Habib U, \& Khan R (2018). There's No Such Thing as Free Lunch but Envy among Young Facebookers. KSII Transactions on Int \& Infor Syst 12(10).

28. Cable DM, \& DeRue D S (2002). The convergent and discriminant validity of subjective fit perceptions. $J$ of applied psycho 87(5): 875.

29. Cable DM, \& Judge TA (1996). Person-organization fit, job choice decisions, and organizational entry. Org Beh and Human Deci proc 67(3): 294-311.

30. Schwarzer R (1993). Measurement of perceived self-efficacy. Forschung an der Freien.

31. Bogler R (2001). The influence of leadership style on teacher job satisfaction. Educational Admin Qua 37(5): 662-683.

32. Williams ES, Konrad TR, Scheckler WE, Pathman DE, Linzer M, McMurray J, \& Schwartz M (2000). The Effects Of Job Satisfaction And Perceived Stress On The Physical And Mental Health And Withdraw Intentions Of Physicians. In Aca of Mgt Proc 2000(1).

33. Spector PE (1997). Job satisfaction: Application, assessment, causes, and consequences (3): Sage publications.

34. Abdulla J, Djebarni R, \& Mellahi K (2011). Determinants of job satisfaction in the UAE.

35. Memon MA, Salleh R, Mirza MZ, Cheah JH, Ting H, Ahmad MS, \& Tariq A (2020). Satisfaction matters: the relationships between HRM practices, work engagement and turnover intention. Int $J$ of Manp. 
36. Shanahan C, Best C, Finch M, \& Sutton C (2007). Measurement of the behavioural, cognitive, and motivational factors underlying team performance. Defence Science and Technology Organisation Edinburgh (Australia) Air Operations Div.

37. Sabri PSU, Ilyas $M, \&$ Amjad $Z$ (2011). Organizational culture and its impact on the job satisfaction of the University teachers of Lahore. Int $J$ of Bus and Soci Sci 2(24).

38. Krejcie RV, \& Morgan DW (1970). Determining sample size for research activities. Educational and Psycho Measu 30(3): 607-610.

39. Maxwell JA (2019). Distinguishing between quantitative and qualitative research: A response to Morgan. $J$ of Mix Mld Res 13(2): 132-137.

40. Hair A (1998). Tatham, and Black. Análisis multivariante.

41. Hu LT, \& Bentler PM (1999). Cutoff criteria for fit indexes in covariance structure analysis: Conventional criteria versus new alternatives. Stru Equ Mode: A Multi J 6(1): 1-55.

42. Chin WW, \& Todd PA (1995). On the use, usefulness, and ease of use of structural equation modeling in MIS research: a note of caution. MIS Quart 237-246.

43. Jöreskog KG, \& Sörbom D (1996). PRELIS 2 user's reference guide: $A$ program for multivariate data screening and data summarization: A preprocessor for LISREL. Scientific Software International.

44. Ghasemi B, \& Aminossadati SM (2010). Brownian motion of nanoparticles in a triangular enclosure with natural convection. Int $J$ of Thermal Sci 49(6): 931-940.

45. Green SB, Akey TM, Fleming KK, Hershberger SL, \& Marquis JG (1997). Effect of the number of scale points on chi-square fit indices in confirmatory factor analysis. Structural Equation Modeling: $A$ Multidis J 4(2): 108-120.
46. Bagozzi RP, \& Yi Y (2012). Specification, evaluation, and interpretation of structural equation models. $J$ of the Academy of $M k t$ Sci 40(1): 8-34.

47. Nafari N, \& Vatankhah S (2016). Investigating the Effect of Empowerment on Employees' Occupational Self-Efficacy. Bulletin de la Société Royale des Sciences de Liège 85: 1434-1447.

48. Peng J, Li D, Zhang Z, Tian Y, Miao D, Xiao W, \& Zhang J (2016). How can core self-evaluations influence job burnout? The key roles of organizational commitment and job satisfaction. $J$ of Health psycho 21(1): 50-59.

49. Din MU, Khan F, Kadarningsih A, Ali A, \& Astuti SD (2019). The Moderating Role of Employee Empowerment and Distributive Justice in Transformational Leadership with Its Impact on Organizational Commitment in Islamic Banks at Pakistan. Perisai: Islamic Bank and Finan J 3(2): 135.

50. Xie X, Zhu Q, \& Qi G (2020). How can green training promote employee career growth?.J of Cleaner Prod 120818.

51. Livne Y, \& Goussinsky R (2018). Workplace bullying and burnout among healthcare employees: The moderating effect of control-related resources. Nursing \& Heal Sci 20(1): 89-98.

52. Shoji K, Cieslak R, Smoktunowicz E, Rogala A, Benight CC, \& Luszczynska A (2016). Associations between job burnout and self-efficacy: a meta-analysis. Anxiety, Stress, \& Coping 29(4): 367-386.

53. Mo S, \& Shi J (2017). Linking ethical leadership to employee burnout, workplace deviance and performance: Testing the mediating roles of trust in leader and surface acting. $J$ of Bus Ethics 144(2): 293-303. 
54. O'Connor PJ, Stone S, Walker BR, \& Jackson CJ (2017). Deviant behavior in constrained environments: Sensation-seeking predicts workplace deviance in shallow learners. Personality and Ind Diff 108: 20-25.

55. Lok P, \& Crawford J (2004). The effect of organisational culture and leadership style on job satisfaction and organisational commitment. Journal of management development.

56. Kukunuru S, Pillai MR, \& Kassem AA (2019). Creating Happiness at Workplace: Work Team Contributions and Concerns. J of Comp and Theor Nanosci 16(12): 5313-5326.

57. Idris A, See D, \& Coughlan P (2018). Employee empowerment and job satisfaction in urban Malaysia. $J$ of Org Change Mgt.

58. MacPhee M, Dahinten VS, \& Havaei F (2017). The impact of heavy perceived nurse workloads on patient and nurse outcomes. Admin Sci 7(1): 7.

59. Nielsen I, \& Smyth R (2008). Job satisfaction and response to incentives among China's urban workforce. The $J$ of Socio-Econ 37(5): 1921-1936.

60. Tan TH, \& Waheed A (2011). Herzberg's motivation-hygiene theory and job satisfaction in the Malaysian retail sector: The mediating effect of love of money 45(2): 164-171.

61. Han K, Trinkoff AM, \& Gurses AP (2015). Work-related factors, job satisfaction and intent to leave the current job among United States nurses. J of Clinical Nurs 24(3): 32243232.

62. Raza MY, Akhtar MW, Husnain M, \& Akhtar MS (2015). The impact of intrinsic motivation on employee's job satisfaction. Mgt and Org Stu 2(3): 80-88.

63. Mafini C, \& Pooe DR (2013). The relationship between employee satisfaction and organisational performance: Evidence from a South African government department. $S A J$ of Indu Psycho 39(1): 00-00.

64. Griffin MA, Patterson MG, \& West MA (2001). Job satisfaction and teamwork: The role of supervisor support. J of Org Beh: The Int J of Indu, Occup and Org Psycho and Beh22(5): 537-550.

65. Kim SE, Kim CW, Lee SJ, Oh JH, Lee DH, Lim TH, \& Choi YH (2015). A questionnaire survey exploring healthcare professionals' attitudes towards teamwork and safety in acute care areas in South Korea. BMJ Open 5(7).

66. Dalege J, Borsboom D, van Harreveld $\mathrm{F}$, van den Berg $\mathrm{H}$, Conner $\mathrm{M}$, \& van der Maas HL (2016). Toward a formalized account of attitudes: The Causal Attitude Network (CAN) model. Psycho Rev 123(1): 2-22. 